\title{
THE TAXONOMY OF THE TRAVERSODONTID CYNODONTS EXAERETODON AND ISCHIGNATHUS
}

\author{
JUN LIU \\ Institute of Vertebrate Paleontology and Paleoanthropology, Chinese Academy of Sciences, Beijing, 100044 China. \\ liujun@ivpp.ac.cn
}

\begin{abstract}
This paper addresses some issues about the taxonomy of two traversodontid cynodonts: Exaeretodon. and Ischignathus. The type species of Exaeretodon, a Late Triassic genus, is E. frenguellii, but the valid name of the Argentinian species is E. argentinus. Another species of this genus is E. riograndensis from Brazil. Part of the holotype of Traversodon major from Brazil, that was subsequently allocated in Exaeretodon, as well as Exaeretodon statisticae from India, are considered as indeterminate species of Exaeretodon. After a detailed discussion of the diagnoses of Ischignathus sudamericanus, this taxon is regarded as a junior synonym of Exaeretodon argentinus.
\end{abstract}

Key words: Taxonomy, Traversodontidae, Exaeretodon, Ischignathus, Triassic, South America.

RESUMO - Este trabalho trata da taxonomia de dois gêneros de cinodontes traversodontídeos: Exaeretodon e Ischignathus. A espécie tipo de Exaeretodon, gênero do final do Triássico, é E. frenguellii, mas o nome válido para a especie argentina é E. argentinus. Uma outra espécie deste genero é E. riograndensis do Brasil. Parte do holótipo de Traversodon major do Brasil, que subsequentemente foi alocado em Exaeretodon, bem como Exaeretodon statisticae da India, são considerados como espécies indeterminadas de Exaeretodon. Após detalhada discussão da diagnose de Ischignathus sudamericanus, este táxon é reconhecido como sinônimo junior de Exaeretodon argentinus.

Palavras-chave: Taxonomia, Traversodontida, Exaeretodon, Ischignathus, Triássico, América do Sul.

\section{INTRODUCTION}

Cabrera (1943) described the first remains of cynodonts from the Ischigualasto Basin, Triassic of Argentina and proposed three different taxa: Belesodon? argentinus, Exaeretodon frenguellii, and Theropsis robusta. Bonaparte (1962) considered these species as belonging to the genus Exaeretodon, in which he recognized two species, E. argentinus and E. frenguellii, the latter being proposed as the synonym of Theropsis robusta. Later, Bonaparte (1963) erected another new species of a traversodontid cynodont from the Ischigulasto Formation, Proexaeretodon vincei. In their review of cynodonts, Hopson \& Kitching (1972) proposed the synonymy of Exaeretodon argentinus, E. frenguellii and Proexaeretodon vincei, under the species name of $E$. argentinus based on page priority. This opinion was adopted by Brink (1988). However, Exaeretodon frenguellii was considered as the valid species name by Battail (1991) and Abdala et al. (2002). Some fragmentary materials of a traversodontid cynodont from the Brazilian Santa Maria Formation was named as Traversodon? major (von Huene 1936). This species was synonymized to $T$. stahleckeri by Hopson \& Kitching (1972; see also Brink, 1982), but part of this material, a fragment of maxilla without teeth, was included in the new species Exaeretodon major by Barberena (1974), and later synonymized to E. frenguellii by Battail (1991). Abdala et al. (2002) favored recognizing $E$. major as a distinct species. A species from India, Exaeretodon statisticae (Chatterjee, 1982) is also regarded as a junior synonym of $E$. frenguellii by Battail (1991). Recently, another species, E. riograndensis, was named for cranial material from the Santa Maria Formation (Abdala et al., 2002).

Bonaparte (1963) named one genus and species, Ischignathus sudamericanus, based on the specimen PVL 2564 from the Ischigualasto Formation. Because it has same postcanine morphology and similar skull pattern as Exaeretodon, and the characters are built on the largest specimen of Traversodontidae, it is reasonable to doubt that the diagnostic characters could be ontogenetic variation. However, no further work on this hypothesis has been done, and the validation of this genus and species has been accepted in all previous studies. Up to now, only the holotype (MLP 42-VII-14-2) and two mandibles (PVL 2552 and PVL 3803) have been referred to this species (Abdala, 2000). In this paper, the taxonomy and diagnostic characters of Exaeretodon and Ischignathus are discussed.

\section{METHODS}

To test the validity of the diagnostic features of Ischignathus sudamericanus, five measurements of skulls and nine of the lower jaw were used in the analysis (Figure 1). The values of the skull were rectified from the measurements on both sides. Because the dentary series of the lower jaw 
are distinctly asymmetric for left and right side, the value on both sides were measured. The length of the dentary body is nearly equal on the two sides; thus, if this value can only be obtained on one side, the same value was applied to the other side in analysis.

Following a method similar to that described by Abdala \& Giannini (2000), bivariate analysis of allometry was used to test the hypothesis that all specimens of Exaeretodon and Ischignathus from the Ischigualasto Formation represent a single species. The relation of any two variables can be studied through the equation of allometry: $\ln Y=a \ln X+b$ which is derived from the exponential growth equation $\mathrm{Y}=\mathrm{bXa}$ (Alexander, 1985) by the calculation of the natural logarithm. Here, "a" is the slope of the line or coefficient of allometry and "b" is the y-intercept. Because both variables have measurement error, natural variation, and the same units of measurement, major axis regression (MAR) is appropriate for this study. The significance of the difference in slope value was assessed with a t-test.

Institutional Abbreviations. BP, Bernard Price Institute for Palaeontological Research, Johannesburg; GPIT, Institut und Museum für Geologie und Paläontologie der Universität Tübingen, Tübingen; ISIR, Geological Museum, Indian Statistical Institute, Calcutta; MACN, Museo Argentino de

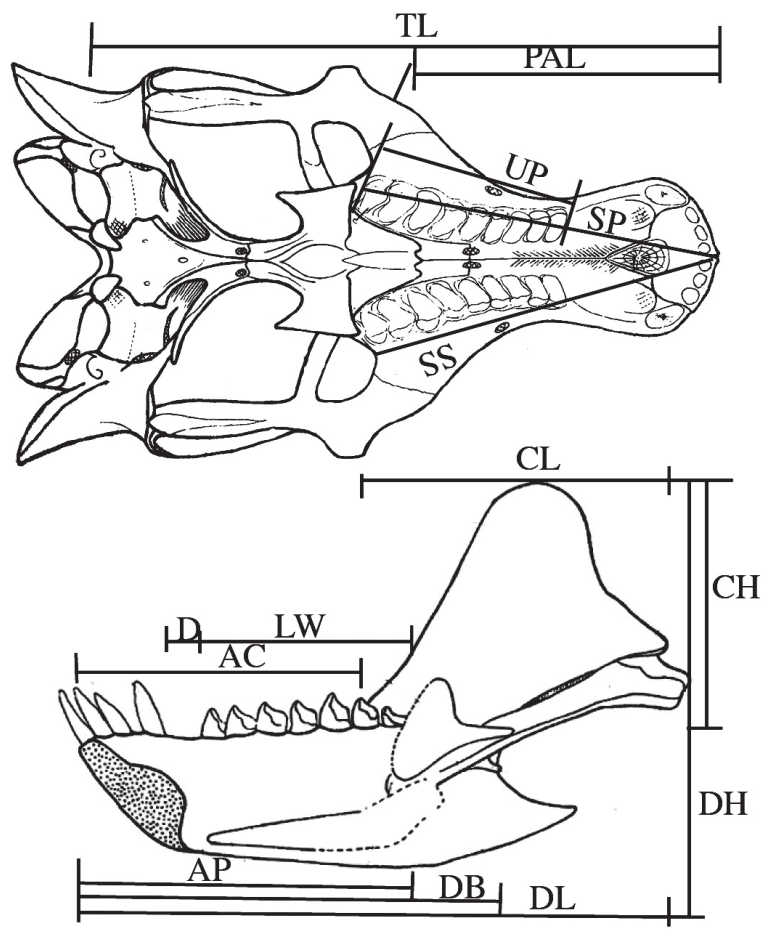

Figure1. Measurements used in this study. Abbreviations: AC, length from anterior tip of dentary to the base of the coronoid process; AP, length from anterior tip of dentary to the end of the tooth row; $\mathbf{C L}$, coronoid process length; $\mathbf{C H}$, coronoid process height; $\mathbf{D}$, diastema between canine and first postcanine; DB, dentary body length, from anterior tip of dentary to concave place anterior to angular process; DH, dentary height; DL, dentary length; LW, lower postcanine row length; OD, orbit diameter (not showed here); PAL, palate length; SP, length from tip of snout to the end of the tooth row; SS, length from tip of snout to subtemporal fossa; TL, total skull length, from anterior tip of snout to occipital condyles; UP, upper postcanine row length. Drawings are from Bonaparte (1962).
Ciencias Naturales "Bernardino Rivadavia", Buenos Aires; MCP, Museu de Ciências e Tecnologia, Porto Alegre; MCZ, Museum of Comparative Zoology, Harvard University, Cambridge; MLP, Museo de La Plata, La Plata; PVL, colección de Palaeontología de Vertebrados, Instituto Miguel Lillo, Universidad Nacional de Tucumán, San Miguel de Tucumán; PVSJ, Museo de Ciencias Naturales, Universidad Nacional de San Juan, San Juan.

\section{Examined material}

Type material. BP/1/5395, holotype of Scalenodontoides macrodontes. MCP 1522-PV, holotype of Exaeretodon riograndensis Abdala et al. 2002. MLP 42-VII-14-2, holotype of Exaeretodon argentinus (Cabrera 1943). PVL 2564, holotype of Ischignathus sudamericanus Bonaparte 1963.

Non-type materials. MACN 18125; MACN 18200; PVL 1893, PVL 2056, PVL 2066, PVL 2079, PVL 2082, PVL 2083, PVL 2085, PVL 2093, PVL 2094, PVL 2109, PVL 2467, PVL 2468, PVL 2473, PVL 2503, PVL 2750; PVS J103, PVS 707; MCZ MCZ 4468, MCZ 4470, MCZ 4472, MCZ 4478, MCZ 4483, MCZ 4486, MCZ 4493, MCZ 4505.

\section{TAXONOMY OF EXAERETODON}

Following article 68.2 of the International Code of Zoological Nomenclature (1999), the type species of Exaeretodon should be E. frenguellii because it is the type species by original designation. Accepted as the synonym of $E$. argentinus and $E$. frenguellii, only the oldest name is valid based on the principle of priority (article 23), and it is $E$. argentinus because of its page priority. If two names are regarded as simultaneously published, the validation of the names should be determined by the first reviser (article 24.2). The name also should be E. argentinus because Hopson \& Kitching (1972) were the first reviser. There is only one valid species for this genus in Argentina up to now.

The materials assigned to ?Traversodon major include different fragmentary bones from various sites of the Santa Maria Formation (von Huene, 1936). One of them, a fragmentary maxilla with seven alveoli for postcanines but no teeth, was assigned to Exaeretodon by Barberena (1974), on the basis of the angulations of the postcanine alveolus. Abdala et al. (2002) maintained it as a separate species of Exaeretodon because of the conspicuous difference in size between the anterior and posterior alveoli, contrasting with the small size variation of postcanines in E. riograndensis, but arguing that more material would be necessary to prove the validity of $E$. major. The similarity of this species with Exaeretodon is represented by the presence of angulation in the postcanine alveoli suggesting the presence of shouldering in upper postcanines. However, as mentioned by Abdala et al. (2002), the difference in tooth size of the same postcanine series is not definitely diagnostic for traversodontid species. In Exaeretodon argentinus, the difference in size between the anterior and posterior postcanines varies in different specimens; e.g., the posterior postcanines are much larger than anterior ones in PVL 2565 while the size variation is much smaller in PVL 2079. Therefore, 


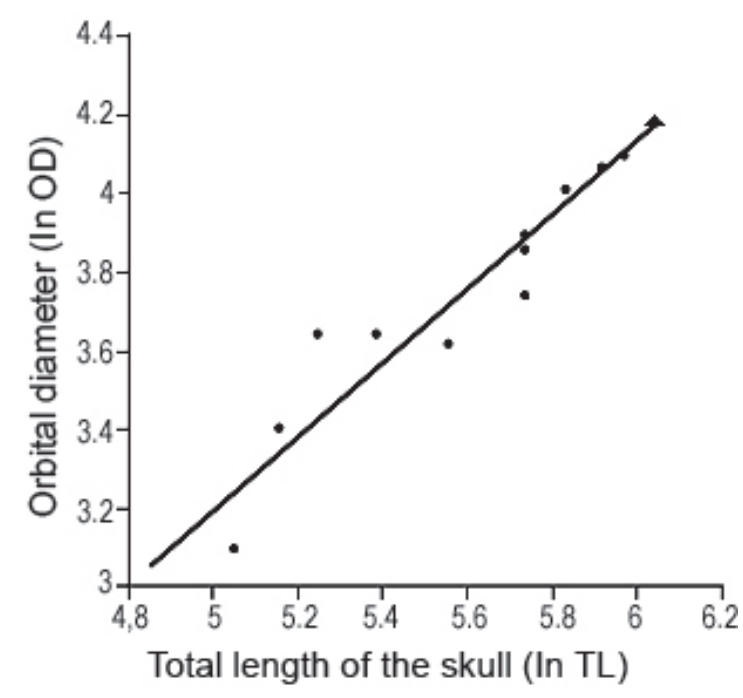

Figure 2. Regression of orbit diameter (In OD) on total skull length (In TL) in Ischignathus (triangle) and Exaeretodon specimens.

the difference in tooth size of the same postcanine series is not a good criterion to suggest Exaeretodon major as a distinct species. As no basicranial material is available for the specimens identified as Exaeretodon major, it cannot be assigned to either E. argentinus or E. riograndensis, and it is better to consider this specimen as an indeterminate species within Exaeretodon.

The holotype of Exaeretodon statisticae includes a partial skull with lower jaw (ISIR 304). Chatterjee (1982) proposed that this species differs from Exaeretodon argentinus in the weaker development of both labial accessory cusps, lack of fluting between central and posterior cusps; and the transverse lingual basin narrow and shallow. Its tooth structure is very close to that of Exaeretodon argentinus, and thus, it was identified within Exaeretodon; however, the slight difference could be due to erosion during chewing, and thus, it is regarded as a synonym of E. argentinus by Battail (1991). The synonym of Exaeretodon statisticae with E. argentinus by Battail is reasonable because the latter species is the only known taxon with the same kind of upper postcanines in 1991. However, the discovery of Exaeretodon riograndensis invalidated the synonym of E. statisticae with E. argentinus. Exaeretodon riograndensis differs from $E$. argentinus in the presence of crests in the lateral flange of the prootic. Because the prootic was not preserved in the Indian material, and the postcanine structure is similar for all materials of Exaeretodon, the Indian specimen can be assigned to either species. The same kind of upper postcanines of Exaeretodon is also described in Scalenodontoides (BPI 1/5395; Gow \& Hancox, 1993), indicating that ISIR 304 can be assigned out of Exaeretodon on the basis of their postcanines. However, the lower jaw of ISIR 304 is similar to that of E. argentinus but differs from that of Scalenodontoides; therefore, the Indian specimen ISIR 304 is currently identified as an indeterminate species within Exaeretodon also.

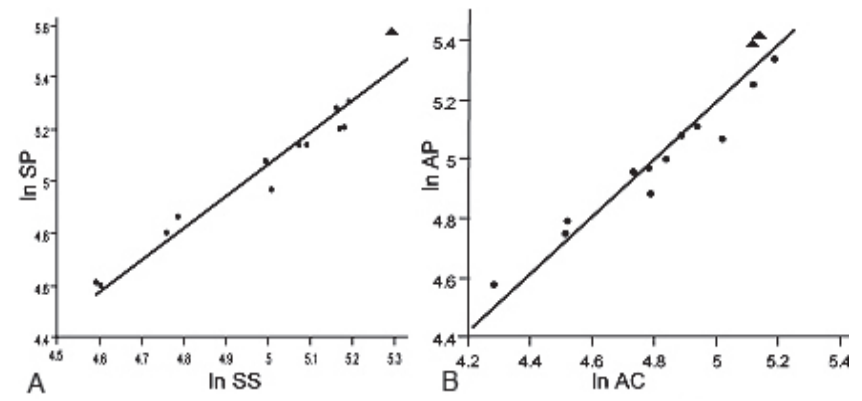

Figure 3. Graphs comparing Ischignathus (triangle) and Exaeretodon. A, regression of upper tooth row (In SP) on subtemporal fossa (In SS); B, regression of lower tooth row (In $\mathrm{AP}$ ) on dentary length anterior to the coracoid process (In AC).

\section{ON THE TAXONOMIC IDENTITY OF ISCHIGNATHUS SUDAMERICANUS}

Because there is no crest on the lateral flange of the prootic of the holotype of Ischignathus, and as this specimen was discovered in the Ischigualasto Formation, if it belongs to Exaeretodon, it should be E. argentinus rather than E. riograndensis.

The monotypic genus Ischignathus is characterized by "the row of maxillary teeth placed more medially and parallel than in Exaeretodon; palatines are anteroposteriorly longer than in other traversodontids; more maxillary molars placed medially to the subtemporal fossa and more mandibular molars placed medially to the ascending rama of the dentary than in Exaeretodon. The orbital cavity is axially longer than in other traversodontids, and the ascending rama of the dentary more expanded both dorsoventrally and anteroposteriorly than in Exaeretodon" (Bonaparte, 1963). Although there is doubt about the validation of this taxon, this genus has been accepted in all classifications, including those of Hopson \& Kitching (1972), Battail (1991) and Abdala (2000). The diagnostic characters proposed by Bonaparte (1963) are discussed below on the basis of the results obtained from an analysis of allometry.

\section{RESULTS AND DISCUSSION}

The results of regression analysis showed that most measurements are well correlated (Table1), and the specimen PVL 2564 (triangle in the Figures 2 and 3) is close to the regression line of other specimens. The characters listed by Bonaparte (1963) for Ischignathus sudamericanus are discussed below:

The orbital cavity is axially longer than in other Traversodontids. This is correct; the orbital diameters of MCZ $4486(60 \mathrm{~mm})$, PVL2564 $(65 \mathrm{~mm})$ are the largest among all known specimens. However, this is due to the absolute size of these specimens, which are the largest among all known traversodontids. Their relative sizes $(\mathrm{OD} / \mathrm{TL}=0.15)$ are less than some small specimens of Exaretodon (i.e., 0.17 in MCZ 4493). In tetrapods, the size of the orbit generally grows with negative allometry. This is validated by the plot of OD vs. TL 
Table1. Results of major axis regression. Abbreviations: $\mathbf{N}$, sample size; a, coefficient of allometry; b, y-intercept; R2, coefficient of determination; $\mathbf{P}(\mathbf{a}=1)$, possibility of isometric growth. Values of $\mathbf{a}$ distinct from $a=0$ with $p<0.001$. Other abbreviations as Figure 1.

\begin{tabular}{c|c|ccccc}
$\mathbf{Y}$ & $\mathbf{X}$ & $\mathbf{N}$ & $\mathbf{a}$ & $\mathbf{b}$ & $\mathbf{R}^{2}$ & $\mathbf{P}(\mathbf{a}=\mathbf{1})$ \\
\hline $\mathbf{P A L}$ & $\mathrm{TL}$ & 15 & 1.10 & -1.40 & 0.94 & 0.18 \\
$\mathbf{S P}$ & $\mathrm{TL}$ & 14 & 0.99 & -0.51 & 0.96 & 0.91 \\
$\mathbf{S S}$ & $\mathrm{TL}$ & 16 & 0.88 & 0.08 & 0.96 & 0.01 \\
OD & $\mathrm{TL}$ & 12 & 0.95 & -1.56 & 0.90 & 0.58 \\
UP & $\mathrm{TL}$ & 14 & 0.89 & -0.54 & 0.70 & 0.40 \\
SP & $\mathbf{S S}$ & 13 & 1.22 & -1.05 & 0.94 & 0.03 \\
AP & $\mathbf{A C}$ & 15 & 0.96 & 0.41 & 0.93 & 0.55 \\
\hline
\end{tabular}

Table 2. Comparison of some ratios among different specimens of Exaeretodon. Dentary length (DL) in $\mathrm{mm}$. Abbreviations as Figure 1.

\begin{tabular}{c|ccccc} 
& PVL & PVSJ & MACN & PL & PVL \\
& $\mathbf{2 5 6 4}$ & $\mathbf{1 0 3}$ & $\mathbf{1 8 1 2 5}$ & $\mathbf{2 0 9 3}$ & $\mathbf{2 4 6 7}$ \\
\hline DL & 395 & 371 & 360 & 263 & 253 \\
CH/DH & 0.66 & 0.66 & 0.66 & 0.59 & 0.64 \\
CH/DL & 0.45 & 0.40 & 0.40 & 0.47 & 0.42 \\
CL/DL & 0.61 & 0.57 & 0.58 & 0.47 & 0.53 \\
\hline
\end{tabular}

(Figure 2), although it is not remarkably distinct from isometry. The palatines are anterior-posteriorly longer than in other Traversodontids. Because the anterior suture with the maxilla is unclear, the length cannot be directly measured. However, the absolute length should be longer than others due to its large size. Because the posterior end of the palatine levels around the posterior end of the tooth rows, the length of palatine can be partially estimated by the length from the tip of the snout to the end of the tooth row (SP). SP is isometric in relation to the TL $(a=0.99)$. Furthermore, because the palate length grows fast relative to the skull length $(a=1.10)$, the posterior part of palatines should show negative allometric growth relative to skull length. The ratio of the length of the posterior portion of the palatine to skull length is actually smaller in PVL 2564 than those in MCZ 4470 and PVL 2094.

More upper postcanines medially to the subtemporal fossa and more lower postcanines medially to the ascending branch of the coronoid process than in Exaeretodon. These are distinguished features of PVL 2564. The relative length of maxillary teeth posterior to the subtemporal fossa is greatest in PVL 2564; this can be explained by the positive allometric growth of SP relative to SS (Table 1, Figure 3A). For mandibular teeth, the length within the coronoid process in PVL 2564 is shorter than in MACN 18125; even if this one is excluded, the relative length still is less than for some smaller specimens. The plot shows AP with slightly negative allometric growth relative to AC (Table 1, Figure 3B).

The dentary ascending branch more expanded dorsoventrally and anteroposteriorly than in Exaeretodon. This is not true, their relative size is similar to that of other specimens, especially similar size specimens (Table 2).

Based on the this analysis, it is reasonable to assign PVL 2564 as a large size specimen of Exaeretodon and Ischignathus as a junior synonym of Exaeretodon.

\section{ACKNOWLEDGMENTS}

I would like to thank J. Powell (PVL), C. Schaff (MCZ) and M. C. Malabarba (MCP) for accessing the specimens; M. Maisch (GPIT) kindly provided photographs of traversodontids housed in the Tubingen collection. I especially thank Abdala's family host in Tucuman and $\mathrm{Wu}$ Shaoyuan's host in Boston.

\section{REFERENCES}

Abdala, F. 2000. Catalogue of non-mammalian cynodonts in the Vertebrate Paleontology Collection of the Institute Miguel Lillo, Universidad Nacional de Tucuman, with comments on species. Ameghiniana, 37:463-476.

Abdala, F.; Barberena, M.C. \& Dornelles, J. 2002. A new species of the traversodontid cynodont Exaeretodon from the Santa Maria Formation (Middle/Late Triassic) of southern Brazil. Journal of Vertebrate Paleontology, 22:313-325.

Abdala, F. \& Giannini, N.P. 2000. Gomphodont cynodonts of the Chanares Formation: the analysis of an ontogenetic sequence. Journal of Vertebrate Paleontology, 20(3):501-506.

Alexander, R.M. 1985. Body support, scaling and allometry. In: M. Hildebrand, D.M. Bramble, K.F. Liem \& D.B. Wake (eds.) Functional vertebrate morphology, Belknap Press, p. 27-37.

Barberena, M.C. 1974. Contribuição ao Conhecimento dos Cinodontes Gonfodontes (Cynodontia, Tritylodontoidea) do Brasil.Curso de Pós-Graduação em Geociências,Universidade Federal do Rio Grande do Sul, PhD. Dissertation, 194 p.

Battail, B. 1991. Les Cynodontes (Reptilia, Therapsida); une phylogenie. Bulletin du Museum National d'Histoire Naturelle. Section C, 13:17-105.

Bonaparte, J.F. 1962. Descripción del craneo y mandibula de Exaeretodon frenguellii Cabrera, y su comparacion con Diademodontidae, Tritylodontidae y los cinodontes sudamericanos. Publicaciones del Museo Municipal de Ciencias Naturales y Tradicional de Mar del Plata, 1:135-202.

Bonaparte, J.F. 1963. Un nuevo cinodonte gonfodonte del Triasico Medio Superior de San Juan, Proexaeretodon vincei n. gen., n. sp. (Cynodontia-Traversodontidae). Acta Geologica Lilloana, 4:129-133.

Brink, A.S. 1982. Illustrated bibliographical catalogue of the Synapsida. Part 1. Department of Mineral and Energy Affairs, South Africa Geological Survey, Pretoria, 35 p. (Handbook 10)

Cabrera, A. 1943. El primer hallazgo de terapsidos en la Argentina. Notas del Museo de La Plata, 8:317-331.

Chatterjee, S. 1982. A new cynodont reptile from the Triassic of India. Journal of Paleontology, 56:203-214.

Gow, C.E. \& Hancox, P.J. 1993. First complete skull of the Late Triassic Scalenodontoides (Reptilia, Cynodontia) from southern Africa. In: S.G. Lucas \& M. Morales (eds.) The nonmarine Triassic, 161-168 p.

Hopson, J.A. \& Kitching, J.W. 1972. A revised classification of cynodonts (Reptilia; Therapsida). Palaeontologia Africana, 14:71-85.

von Huene, F. 1936. Die fossilen Reptilien des südamerikanischen Gondwanalandes an der Zeitenwende. Ergebnisse der Sauriergrabungen in Südbrasilien, 1928-29. Lieferung 2, Tübingen, Verlag Franz F. Heine, 66 p.

ICZN. 1999. International code of zoological nomenclature. The International Trust for Zoological Nomenclature, London, 306.

Received in April, 2007; accepted in June, 2007. 